\title{
Contra-archivos: estrategias de apropiación de imágenes y sonidos de perpretadores
}

\author{
Mariano Veliz*
}

Resumo: O artigo analisa dois curta-metragens da diretora paraguaia Paz Encina, Familiar (2014) y Arribo (2014). O seu trabalho com imagens e sons do Archivo del Terror do Paraguay leva a questionar tanto a possibilidade de desmantelar a sua função repressora inicial como a conversão do prontuário em retrato de resistência.

Palavras-chave: arquivo, cinema, Paraguai, prontuário, retrato.

Resumen: El artículo se propone analizar dos cortometrajes de la cineasta paraguaya Paz Encina, Familiar (2014) y Arribo (2014), realizados a partir de su investigación en el Archivo del Terror de la dictadura de Alfredo Stroessner. Su trabajo con imágenes y sonidos procedentes de un archivo represivo interroga tanto la posibilidad de desmantelar su finalidad inicial como su conversión de la foto del prontuario policial en el retrato de la resistencia.

Palabras clave: archivo; Paraguay; prontuario; retrato; cine.

\begin{abstract}
The article investigates two short films directed by the Paraguayan filmmaker Paz Encina, Familiar (2014) y Arribo (2014). Her work with images and sounds from repressive archives of Stroessner's dictatorship leads to a series of questions about the possibility of dismantling its initial purpose and the conversion operated of police records in portraits of resistance.

Keywords: archive; Paraguay; police record; portrait; cinema.
\end{abstract}

Résumé : L'article analyse deux court-métrages réalisés par la réalisatrice paraguayenne Paz Encina, Familiar (2014) et Arribo (2014). Son travail avec des images et des sons issus de fichiers établis au cours de la répression menée au cours de la dictature d'Alfredo Stroessner, conduit à poser une série de questions sur la possibilité de démonter et d'en détourner la fonction initiale et de convertir les photographies de casier judiciaire en portrait de la résistance.

Mots-clés : archives ; Paraguay ; cinéma ; portrait ; casier judiciaire.

* Universidad de Buenos Aires, Facultad de Filosofía y Letras, Instituto Interdisciplinario de Estudios sobre América Latina. 1183, Buenos Aires, Argentina. E-mail: marianoveliz@gmail.com

Sumisión del artículo: 31 de mayo de 2017. Notificación de aceptación: 11 de julio de 2017.

Doc On-line, n. 22, setembro de 2017, www.doc.ubi.pt, pp. 106-121. 
Contra-archivos: estrategias de apropiación de imágenes y sonidos de perpretadores

En 2014 la cineasta paraguaya Paz Encina ${ }^{1}$ (n. 1971) realizó la trilogía Tristezas de la lucha, una serie de cortometrajes que abordan, con diferentes estrategias, la extensa dictadura stronista que gobernó Paraguay entre 1954 y 1989. ${ }^{2}$ El cortometraje que da título a la trilogía se propone como una ficción a partir de textos del escritor español-paraguayo Rafael Barrett. Los otros dos cortometrajes, Arribo y Familiar, se presentan como ensayos fílmicos que intervienen sobre el archivo del Centro de Documentación y Archivo para la Defensa de los Derechos Humanos, conocido como Archivo del Terror, situado en Asunción. ${ }^{3}$

En el contexto del retorno democrático, la desclasificación de los archivos stronistas puso en circulación una cantidad notable de documentos oficiales: fichas, interrogatorios, audios y fotografías. Encina se aventuró en ese material para explorar las historias de los resistentes y construir sus semblanzas. ${ }^{4} \mathrm{Su}$

1. El estreno de su primer largometraje, Hamaca paraguaya (2006), posicionó a Paz Encina en un lugar de privilegio en el marco del cine latinoamericano contemporáneo. En la película se narra la Guerra del Chaco (1932-1935) que enfrentó a Paraguay y Bolivia a través de la historia de una pareja que espera el regreso de su hijo del frente de batalla. Encina propone un relato articulado desde los discursos silenciados y los sujetos invisibilizados por la historiografía oficial. La indagación de la memoria se retoma en su cortometraje Viento sur (2011). Allí, se centra en la historia de dos hermanos perseguidos durante la dictadura de Alfredo Stroessner que deben decidir si partir o no al exilio. En todos los casos, Encina construye films complejos sobre la historia paraguaya del siglo XX, centrados en el funcionamiento de la memoria y dedicados a rediseñar el orden de lo visible, de lo audible y de lo pensable en los discursos oficiales.

2. El golpe de estado que destituyó al Presidente Federico Chaves y colocó en el poder a Alfredo Stroessner no puede pensarse fuera del contexto geopolítico americano y mundial Durante la gestión de Harry Truman como Presidente de Estados Unidos (1945-1953), en el marco de la guerra fría y el temor a la "amenaza soviética", se impuso la célebre Doctrina Truman dedicada a otorgar apoyo financiero a los países que combatieran al comunismo. Se trataba de conseguir así cierto consenso en torno a las concepciones occidentales a cambio de ofrecer tutelaje político y económico. En esa dirección, se impulsó el Tratado Interamericano de Asistencia Recíproca destinado a brindar ayuda a las resistencias nacionales anti-comunistas. La asistencia económica tenía como contrapartida la sumisión a las políticas implementadas por los Estados Unidos. Paraguay fue uno de los primeros países en suscribir este tratado.

En ese marco se produjo el golpe de estado de Stroessner del 4 de mayo de 1954. Su llegada al poder contó con el apoyo del Ejército y el Partido Colorado, a partir de allí las dos bases del sistema represivo instaurado. Durante los casi treinta y cinco años de stronismo, su extremo anti-comunismo se sostuvo con el apoyo de la industria, el Ejército y el gobierno norteamericano. Durante los años ochenta, en una región que atravesaba los procesos de los retornos democráticos, la dictadura paraguaya quedó desfasada. Los cambios en la política internacional, condensados en el abandono del apoyo norteamericano, la consecuente caída de la economía, y las pujas en el interior del Partido Colorado terminaron con el derrocamiento de Stroessner por un nuevo golpe de estado dado por su consuegro, el General Andrés Rodríguez Pedotti el 3 de febrero de 1989.

3. El hallazgo de estos archivos constituye una de las particularidades más notables del proceso del retorno democrático paraguayo. Por un lado, esto se debe a que en ningún otro país de la región se desclasificaron archivos de tal envergadura, tanto en términos cuantitativos como cualitativos. La información que consta en los documentos hallados da cuenta, de manera rigurosa, del funcionamiento de la dictadura de Stroessner y de la implementación del Plan Cóndor. Por otro lado, la aparición de los archivos motivó todo tipo de pujas por parte de sectores del poder político y económico que intentaron invisibilizar los documentos y reducir su impacto sobre la sociedad civil.

4. Estos cortometrajes se vinculan con Notas de memoria, una serie de videoinstalaciones realizadas por Encina en diciembre de 2012 en distintos espacios públicos de Asunción. 
acercamiento abre una serie de interrogantes: ¿qué apropiación puede hacerse del arsenal fotográfico y sonoro de la dictadura?, ¿cómo puede interrogarse la historia a partir de estos archivos?, ¿es posible desmontar el vínculo de este material con su finalidad represiva?, ¿qué nos dice acerca de la migración de las imágenes y los sonidos?

\section{El Archivo del Terror}

En El cuerpo y el archivo, Alan Sekula afirma que la fotografía, en tanto sistema de representación, puede funcionar tanto honoríficamente (allí se percibe la herencia de los retratos pictóricos) como represivamente. Esta segunda alternativa inaugura la posibilidad de posicionar la fijación fotográfica de delincuentes en el origen de los dispositivos archivísticos implementados por diversos sistemas represivos estatales durante los siglos XX y XXI. Ya en la clausura del siglo XIX, el procedimiento de identificación criminal moderno desarrollado por Alphonse Bertillon para la policía de París incluyó a la fotografía en un lugar preponderante. Sus métodos de individualización antropológica ${ }^{5}$ se reforzaban con la apelación a las fotografías de los sospechosos. En el marco de esta operatividad, Bertillon estandarizó el doble recurso a la imagen de frente y perfil. Así, el fichaje y las ciencias criminológicas se localizan en la base del archivo fotográfico a través de la sumisión de este a las finalidades previstas por el prontuario policial.

Esta inclusión de la imagen identificatoria en el prontuario evidencia que la toma fotográfica funciona allí como un acto performativo. La fotografía no actúa como un mero registro, una simple captura, sino que contribuye con una acción significativa: la creación del enemigo. En la imagen fotográfica se materializa el peligro del adversario. A su vez, esta jerarquización de la imagen fotográfica deriva de la imposición de un régimen de visibilidad centrado en la imbricación del ver, el poder y el saber. La mirada fotográfica es fundadora del archivo y este del sistema represivo.

En la argumentación esgrimida por Sekula, en tanto la fotografía de identificación permite individualizar y "guardar los suficientes antecedentes de una

También debe señalarse que en 2016 Encina estrenó su segundo largometraje, Ejercicios de memoria. Allí, aborda la vida de Agustín Goiburú, un dirigente del Movimiento Popular Colorado (Mopoco) secuestrado y desaparecido durante la dictadura. En este film-ensayo, la cineasta vuelve a indagar en la potencia memorística del Archivo del Terror. A través de la recuperación de los testimonios orales de los hijos y la viuda de Goiburú, Encina radicaliza la puesta en tensión de los archivos represivos y los archivos familiares de las víctimas de la persecución política en Paraguay.

5. Se trataba, como explica Anna María Guasch, de la elaboración de un sistema bipartito basado en el entrecruzamiento de registros microscópicos (lo individual de cada sujeto) y macroscópicos (los rasgos colectivos) "realizado con la voluntad positivista de definir y regular la desviación social" (2011: 169). 
personalidad para poder identificar la actual descripción con la que se pueda presentar en el futuro" (2003: 159), el archivo fotográfico policial se instaura como una máquina biográfica. El archivo fotográfico no solo colabora con la creación y reconocimiento del enemigo, sino que escribe también su biografía.

Los archivos organizados en Paraguay durante la dictadura de Alfredo Stroessner se adhirieron desde su origen a esta matriz. El archivo stronista, como todo archivo represivo, se dedicaba a asegurar la unificación, identificación y clasificación de los fichados. En este sentido, como precisa Sekula, la unidad inicial del archivo resulta siempre impuesta por su propietario.

En los años posteriores al fin de la dictadura stronista se iniciaron investigaciones judiciales que condujeron a una serie de hallazgos archivísticos. El 22 de diciembre de 1992 fue allanado el Departamento de Producciones de la Policía, situado en la ciudad de Lambaré, a $4 \mathrm{~km}$. de la capital. ${ }^{6}$ Dos días después fue allanada la Dirección Nacional de Asuntos Técnicos. Estos primeros procedimientos permitieron acceder a una cantidad ingente de documentos de los primeros años del gobierno de Stroessner; en particular del período comprendido entre 1958 y 1965 . En esos años se había puesto en funcionamiento la Dirección de Fichas de Detenidos Políticos y Documentos Personales dirigida por Antonio Campos Allum. En enero de 1993 se hicieron nuevos allanamientos en el Departamento Judicial de la Policía y en la Comisaría Tercera de Asunción.

Pocos días después se iniciaron los trabajos de inventariado, llevados adelante por funcionarios de la Corte Suprema de Justicia en colaboración con integrantes de organismos de derechos humanos. Los documentos encontrados y catalogados incluyen fichas de detenidos, informes confidenciales, pedidos de búsquedas, declaraciones indagatorias e informativas, controles a partidos políticos de oposición, grupos estudiantiles, sindicatos, controles de entradas y salidas del país, controles telefónicos, vigilancias domiciliarias, publicaciones periodísticas, fotografías, documentos de identidad y cassettes con grabaciones de interrogatorios, programas radiales, conferencias y discursos.

El 26 de marzo de 1993 se creó el Centro de Documentación y Archivo para la Defensa de los Derechos Humanos, dependiente de la Corte Suprema de Justicia de Paraguay. La conformación de este archivo puso en funcionamiento un potente proceso de migración de los documentos y ejecutó así una notoria desvinculación del material archivado con su finalidad inicial.

Esta travesía supone la puesta en crisis de la autoridad hermenéutica original. En Mal de archivo, Jacques Derrida propone concebir al archivo no como

6. El procedimiento fue llevado a cabo por los Doctores José Agustín Fernández y Luis María Benítez Riera. La investigación había sido impulsada, en gran medida, por el periodista Martín Almada. 
un lugar de almacenamiento y conservación de un pasado que existiría de todos modos sin él, sino como un archivo archivante que determina la estructura del contenido archivable en su surgir mismo. Dado que la archivación produce el acontecimiento, el primer archivero instituye el archivo como debe ser. No solo exhibe el documento, sino que lo establece, lo lee, lo interpreta y lo clasifica. La caída de la autoridad hermenéutica original impone una apertura de las lecturas posibles. Y esas lecturas inauguran nuevas interpretaciones y clasificaciones.

Frente al estado monolítico del archivo stronista, la creación del Archivo del Terror implicó la emergencia de un contra-archivo. En "Archive and Aspiration" Arjun Appadurai propone concebir al archivo como una aspiración más que como una recolección. De este modo, el archivo se instaura como el producto de la anticipación de la memoria colectiva. En él se lleva a cabo un combate por el futuro sentido de la historia. Por este motivo, a Appadurai le interesa pensar el contra-archivo como una estrategia de redistribución de la capacidad de aspirar. La conformación de un contra-archivo configura un ejercicio productor de memorias. En ese gesto de intervención se pone de manifiesto la potencia de los contra-archivos para desmontar el funcionamiento represivo y operar una transformación radical de las identidades fichadas. En esta apertura se manifiesta la potencia de convertir los prontuarios de los criminales en los retratos de las víctimas.

La configuración de este contra-archivo asume dos desafíos. Por un lado, como señala Arlette Farge (1991), la desclasificación de los archivos judiciales o policiales impone una estrategia de visibilización basada en la circulación no restrictiva de lo que solía conformar un reducto secreto. Por otro lado, como señala Derrida, el archivo es una cuestión del porvenir. De hecho, es "la cuestión del porvenir mismo, la cuestión de una respuesta, de una promesa y de una responsabilidad para mañana" (Derrida, 1997: 44). En este sentido, si el Archivo del Terror pone en funcionamiento un proceso de migración de los documentos que incluye un desvío de sus finalidades iniciales, pero también una torsión en las identidades de quienes habían sido capturados por los registros oficiales, este proceso se complejiza cuando el arte suma una nueva destinación en esta travesía.

La captura del archivo por parte del arte quiebra la confianza en que la mera mostración implica la inevitabilidad de la lectura. En esa confianza se encuentra agazapada la ingenua creencia en la potencia política y estética del gesto de hacer visible. Sin embargo, la legibilidad del archivo solo es posible a través de la búsqueda de estrategias de intervención. El archivo solo es legible a través de una construcción analítica que le otorgue consistencia epistémica. 
El arte constituye una vía posible para esta construcción. A partir de allí, se esbozan tres preguntas: ¿cómo propiciar la emergencia de estrategias que aseguren la legibilidad del archivo?, ¿cómo convertir la experiencia represiva en experiencia estética?, ¿cómo desmantelar, mediante la intervención sobre el archivo, las máquinas biográficas del archivo policial?

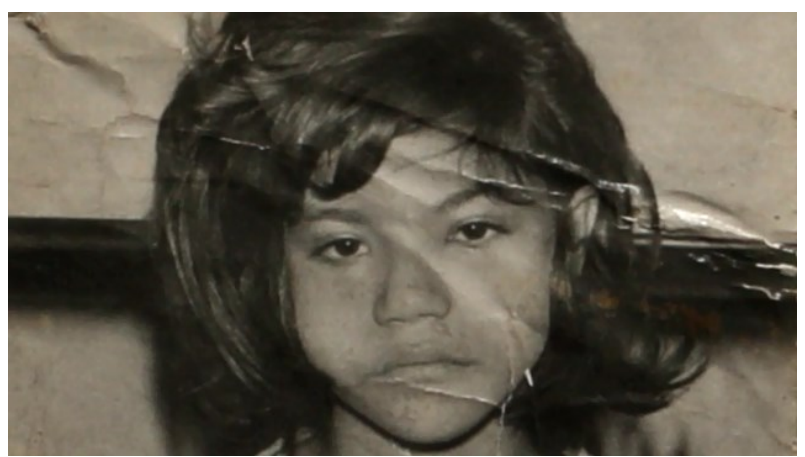

Fig. 1. Fotograma de Familiar (2014), de Paz Encina.

\section{Familiar}

Tanto Familiar como Arribo parten de una asunción: los archivos constituyen el repositorio desde el cual es posible escribir otras historias. Un primer requisito para la gestación de este contradiscurso es el reconocimiento del material de archivo como tal. En concordancia con esta necesidad, los dos cortometrajes concluyen con un cartel que explicita que las imágenes y los audios forman parte del Archivo del Terror. ${ }^{7}$ Sin embargo, la explicitación de este origen problematiza su empleo e instaura una pregunta acerca de la posibilidad de liberarlos de la función originaria para la que fueron concebidos.

El material de archivo al que apela Encina se inscribía en una cadena que conducía, frecuentemente, a la detención, la tortura y la muerte. Son imágenes y audios bajo sospecha que muestran el funcionamiento de la represión desde su interior. Marianne Hirsch (2012) propone la categoría "imágenes de perpetradores" para estudiar aquellas imágenes que se pliegan a una maquinaria de

7. El cartel final de Familiar explicita: "La ficha de Apolonia Flores Rotela y la delación formal forman parte del Centro de Documentación para la Defensa de los Derechos Humanos (Archivo del Terror) situado en Asunción, Paraguay". El de Arribo sostiene: "Las fotografías y el interrogatorio forman parte del Centro de Documentación para la Defensa de los derechos Humanos (Archivo del Terror) situado en Asunción, Paraguay". 
destrucción. ${ }^{8}$ Se trata, como señala Vicente Sánchez Biosca, de imágenes capturadas "ante la carne viva del dolor por quien ejerce (o se encuentra próximo o involucrado con quien lo hace) violencia sobre sus víctimas; violencia en la que la producción visual se convierte en inseparable de la física o psicológica" (2017: 43).

El espectador de estas imágenes experimenta la incomodidad de plegarse a los ojos físicos, y al ojo mecánico, de quienes gobernaban ese dispositivo. Esa mirada carcelaria, a pesar de quedar conservada en el fuera de campo, se inscribe en la imagen. La visión de los verdugos, aunque implícita, impregna la fotografía del prontuario. A su vez, como señala Sánchez Biosca (2017), la fotografía también incluye la respuesta voluntaria o involuntaria del fotografiado. A partir de su imagen puede interrogarse qué ocurrió en el fuera de campo durante el registro y en los tiempos que rodean el disparo fotográfico. La fotografía de identificación de los prontuarios constituye una imagen-huella que señala el hiato entre lo que se muestra y lo que ha pasado. Debido a que el horror suele estar a resguardo de la imagen, es necesario interrogar el linde entre lo que la foto revela y lo que la foto esconde.

Dado que estas imágenes y audios formaban parte de un dispositivo de escucha y visión policial, su propia escucha y visión promueve la incomodidad de compartir la percepción de los perpetradores. El registro no puede aislarse del acto de violencia que envuelve su aparición. En efecto, el propio registro constituye un acto de violencia. Por este motivo, debe analizarse el accionar del dispositivo perceptivo del que emanaron estas imágenes y audios. Frente a esta disyuntiva, emerge la necesidad de evaluar la posibilidad de arrancar estos registros de su origen, volverlos en contra de su funcionalidad inicial y pensarlos como un interrogante lanzado sobre lo no dicho/visto de la historia.

El primer aspecto a tener en cuenta reside en la torsión radical de la circulación prevista. El archivo de la dictadura stronista se definía como un espacio ambiguo entre lo visible y lo invisible, lo audible y lo inaudible. Estaba compuesto por imágenes y audios elaborados para tener una mínima, casi nula, circulación. Extraer este material de esa restricción y promover su incorporación a otras cadenas discursivas supone un gesto de violencia sobre ese archivo. Si este encontraba su poder en su carácter reservado, su exposición en otro espacio, su ofrecimiento a otras miradas, ejerce una primera liberación.

El segundo aspecto destacable consiste en explicitar que todo proceso de apropiación se basa en la dificultad, o imposibilidad, de determinar un significado intrínseco de las imágenes y los audios. En ese vacío originario se

8. Hirsch desarrolla esta categoría en The Generation of Postmemory (2012) a partir del análisis de fotografías tomadas por miembros del ejército alemán en el frente oriental durante la Segunda Guerra Mundial. 
ubica la posibilidad de las apropiaciones posteriores. Allí se inscribe la potencia de uso y reciclaje del archivo. Las imágenes y los audios migran y, en esa migración, pueden alejarse de la cadena de represión y destrucción en la que surgieron. Por este motivo, los documentos archivísticos constituyen los objetos supervivientes que dan cuenta del funcionamiento de un sistema criminal, pero también de la experiencia de la resistencia. La conversión de las fotos de los culpables en las fotos de las víctimas es posible, precisamente, por esta ausencia de un sentido clausurado.

En Familiar, la cineasta recupera un fragmento de la historia de Apolonia Flores, una niña de 12 años integrante de las Ligas Agrarias. Flores fue herida por las fuerzas represivas y detenida en el Policlínico Policial "Rigoberto Caballero". A partir de este episodio de la historia paraguaya, el cortometraje dirigido por Encina se articula en torno a una pregunta que asedia a Georges Didi-Huberman en Remontajes del tiempo padecido: cómo se promueve la legibilidad del archivo, cómo se extrae legibilidad histórica de su visibilidad y audibilidad, cómo se accede a su valor de anamnesis y de conocimiento. La estrategia implementada por Encina coincide con la propuesta por DidiHuberman: erigir al montaje en principio articulador del discurso. En este caso, la primera manifestación del montaje reside en el proceso de recontextualización: el mero hecho de extraer estas imágenes y audios de su espacio de encierro implica un gesto potente de remontaje.

En el prólogo del cortometraje se presenta un procedimiento clave: la discordancia entre la banda sonora y la banda de imagen. Ambas proceden de fuentes distintas: en tanto se escucha el discurso de asunción presidencial de Alfredo Stroessner, en un loop que desnaturaliza, mediante la repetición, las palabras pronunciadas, se alternan dos dimensiones visuales: planos de los momentos previos y posteriores a un partido de fútbol (la llegada de los jugadores, los carteles publicitarios y la bandera nacional presente en el estadio) e imágenes fantasmáticas, borrosas, de un cuerpo infantil apenas percibido entre sombras. En esa tensión entre la oralidad del discurso público y la visibilidad muda de la vida cotidiana se inscribe la potencia del título del cortometraje: el vínculo inescindible de la praxis vital con los acontecimientos históricos. Ese vínculo también se inscribe en la tensión entre el registro oficial de la voz del dictador y las imágenes filmadas en súper 8 , formato que remite a lo hogareño y, precisamente, familiar. Mientras Stroessner asume el poder, la vida cotidiana, condensada en esa práctica social que es el fútbol, parece seguir su curso. Al mismo tiempo, esa imagen espectral remite a la experiencia de la infancia en el contexto dictatorial. Esta figura borrosa instaura una nueva una disyunción temporal. A la incertidumbre en torno a la relación temporal en- 
tre la imagen y el audio se suma la existente entre las dos dimensiones de lo visible.

Desde esta instancia germinal, se propone un desmontaje de los dispositivos de visión y escucha, pero también de las construcciones de la discursividad política y aun de las configuraciones remanidas de la cotidianeidad. Ese trabajo sistemático de desmontaje acentúa, después del prólogo, el conflicto establecido entre la imagen y el sonido. Mientras se escucha una voz masculina, en guaraní, que delata ante el comisario a los hermanos Flores, ${ }^{9}$ la banda de imagen imprime, sobre un fondo negro, pequeñas ventanas que muestran filmaciones familiares, nuevamente en súper 8 , de una fiesta. Después de algunos segundos, el fondo negro se sustituye por el plano detalle de la huella digital de la niña baleada y detenida por la dictadura. A partir de allí, la cámara segmenta y recorre, en un movimiento continuo, la ficha policial. ${ }^{10} \mathrm{El}$ recorrido la conduce a las fotos: una de frente y una de perfil en concordancia con las fotos de identificación.

La aparición del rostro implica la desaparición de las ventanas con las imágenes de la fiesta. Supone también una ruptura mayor: la imagen se detiene sobre ese rostro de frente. Esa pausa resulta clave para evaluar la conversión de la mera foto de identidad, integrada en un prontuario que participa de una cadena de destrucción, en el retrato de una resistente. La suspensión del movimiento se imbrica con la sumatoria de una temporalidad de la pausa que se centra en el rostro de la niña. En esta extensión se cifra la posibilidad de desmontar el funcionamiento del prontuario policial. Ese tiempo brindado al rostro, sin embargo, no deja de estar en tensión permanente con la delación que se escucha. A su vez, luego de algunos segundos, sobre el plano del rostro de la fragilidad se imprime la información consignada en los antecedentes de la detenida, registrados por la Sección Técnica de la Dirección de Política y Afines. El contraste entre el rostro de la niña y la descripción policial radicaliza la estrategia de remontaje operada por Encina.

En la fotografía de la infancia quebrada de Apolonia Flores se inscribe la complejidad derivada de los archivos represivos y sus desclasificaciones. Esta reside, como precisa Danusa Depes Portas, en que el "encuentro con el poder, en el mismo momento en que las deja marcadas de infamia, arranca de la noche del silencio existencias humanas que, de lo contrario, no hubieran de-

9. Luego de unos segundos, se suspende la traducción del guaraní. De esta manera, el corto no queda abrumado por la información una vez que se establece el mecanismo de la delación. A su vez, esta elección acentúa el hiato idiomático. Encina incluye el mismo audio en su segundo largometraje Ejercicios de memoria (2016).

10. Entre la información que consta se encuentra la descripción física, edad, nombre, datos de sus padres, profesión, ideología política, fecha de entrada al país. En este caso, la mayor parte de los casilleros se hallan vacíos. 
jado ninguna señal de sí mismas" (2011: 5). Por eso, en "el acto de rescatar un evento del pasado la obra no devuelve su identidad histórica sino que evidencia e historiza su borrado" (Depes Portas, 2011: 7).

Una vez que concluye la delación, se imprime un nuevo fundido a negro. Allí comienza la coda: el audio de El Danubio Azul de Johann Strauss acompaña tres ventanas que se imprimen sobre un fondo negro: niñas bailando ballet, una fiesta y un desfile cívico. Si hasta ese momento, la principal estrategia del montaje residía en la tensión entre la banda de imagen y la banda sonora, aquí se suma una nueva dimensión: la tensión entre esta secuencia y la anterior, entre la ficha policial de la niña prisionera y la vida cotidiana, familiar, que parece excluida de la historia de la dictadura. El choque impulsado entre esa cotidianeidad anodina, extendida entre el baile presuntamente inocente y el apoyo cívico decidido a la dictadura, y el caso particular de la niña prisionera, refuerza la potencia del título: familiar es no solo la recurrencia a las imágenes hogareñas para encarnar un período de la historia; familiar también es la naturalización del horror y la emergencia de su sombra en las dimensiones más banales de la vida.

En este sentido, el último plano afirma esta complejidad: la imagen penumbrosa de un cuerpo infantil, aparecido ya en el prólogo, inscribe la temporalidad de lo fantasmático y propone una materialización de la crianza espectral en el marco de la dictadura. Esa infancia es el contrapunto de la otra infancia, la arrasada por la violencia institucional. Pero quizás también constituya una formalización de la manera en la que la dictadura se imprimió sobre los cuerpos infantiles, sobre las primeras experiencias, aun aquellas en apariencia alejadas de cualquier vínculo con la política. Esa penumbra de la memoria que opaca el cuerpo infantil está atravesada por el silencio y lo inaudible, por lo oculto e invisible.

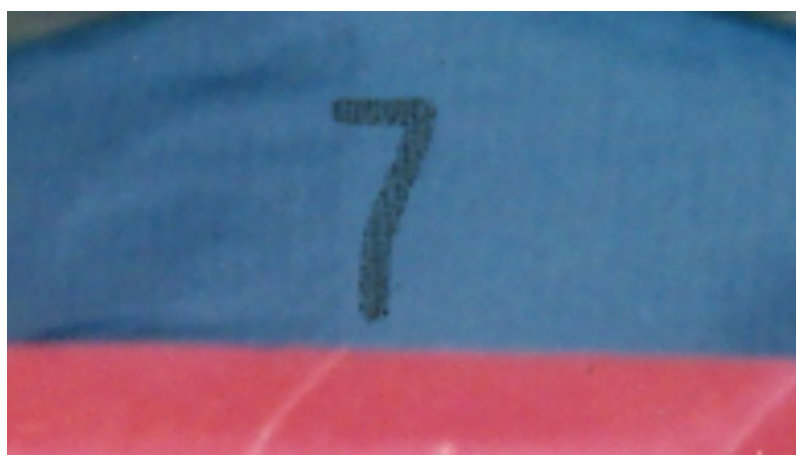

Fig. 2. Fotograma de Arribo (2014), de Paz Encina. 


\section{Arribo}

En Arribo, Encina retoma el interrogatorio al que fue sometido el líder opositor Benigno Perrotta, uno de los fundadores del Partido Revolucionario Febrerista, en su regreso a Paraguay en 1988, tras 27 años de exilio en Argentina. Encina monta el audio del interrogatorio al que fue sometido Perrotta por parte del jefe de la Brigada del aeropuerto y una serie de fotografías pertenecientes también al Archivo del Terror. En este caso, la realizadora lleva adelante una inversión de lo propuesto en Familiar. Si en este, el audio de la delación se tensaba con la foto de identidad de la resistente, en Arribo la escucha de la voz de Perrotta se tensa con la negación de su rostro. En ambos casos, la duración de los cortometrajes está pautada principalmente por la duración del audio: la delación y el interrogatorio respectivamente. ${ }^{11}$

En este sentido, resulta posible recuperar algunas categorías propuestas por Jean-Louis Comolli en "Lo oral y el oráculo" y "Tomar la palabra" para pensar el funcionamiento de la dimensión oral del archivo. Si bien en estos ensayos no se articula una teoría unificada del archivo sonoro, sí se pone en circulación un análisis lúcido y abierto de esta problemática. La primera preocupación, relevante para los cortometrajes de Encina, reside en revisar la separación de la voz y el cuerpo. Para Comolli, la voz es la parte del cuerpo que se proyecta hacia los otros y, por lo tanto, conlleva un resto de sombra. Si la voz filmada constituye ineludiblemente un umbral entre lo visible y lo invisible, en Arribo y Familiar se redobla este carácter liminal dado que no se actualizan en imagen los cuerpos de los que proceden las palabras. La voz aislada de la corporalidad se concibe siempre como la voz de un cuerpo fantasmático. En Arribo esto se radicaliza debido a que Benigno Perrotta falleció en 2011. Sin embargo, su palabra resulta presentificada a través del registro sonoro. Un resto de su propio cuerpo se materializa a través de esa captación de su palabra. Así, se explora no solo la posibilidad de gestar un archivo sonoro, sino de gestar un archivo sonoro que cobije la voz de los ausentes y proceda, mediante el registro, a conservar su huella material.

En esta dirección, una segunda preocupación radica en la necesidad de indagar los restos del cuerpo presentes en la voz. Para Jean-Louis Comolli, siempre hay "rastros de los cuerpos en la voz, pero esos rastros están del lado de lo no-visible" (2017: 235). Por eso es posible interrogar qué se inscribe en la materialidad de las voces, en sus acentos, tonalidades, texturas, alientos, respiraciones. Los parámetros fisiológicos que rigen la emisión de la voz son signos del cuerpo. Por este motivo, el análisis de la voz y la conformación de

11. Se trataba, en ambos casos, de audios que no habían sido explorados y que no habían sido digitalizados por falta de presupuesto. 
un archivo sonoro no pueden desprenderse de la imbricación cuerpo-espaciopalabra-historia. Así, es posible interrogar el tono dubitativo de las respuestas de Perrotta, sus vacilaciones, sus errores. Allí se encarna la distribución del poder, el retorno del exilio y su vinculación con la desposesión territorial, la confrontación de los relatos sobre la historia y, a su vez, la construcción de un relato en función del porvenir, de cómo se quiere ser percibido en el futuro. $\mathrm{El}$ archivo sonoro conserva estas basculaciones de la voz, su oscilación entre el presente, el pasado y el futuro, su linde entre las marcas materiales y las experiencias sensibles.

Si la estructura de Arribo deriva del intercambio desigual entre el Brigadier y el político exiliado, sobresale la resolución de negar el rostro del resistente. Dos operaciones se destinan a desviar la mirada: la fragmentación de las fotografías y el flou sobre las imágenes. De esta manera, no solo se acentúa la tensión entre el audio y la imagen, sino que se incluye la posibilidad de pensar el discurso oral como una materialización particular de una práctica general: los interrogatorios a los exiliados que volvían, transitoria o definitivamente, a Paraguay. La tensión entre la imagen y el audio instaura una tensión entre lo particular y lo general, entre el caso y la práctica estandarizada.

A su vez, dado que el retorno de Perrotta se produjo poco antes de la caída de la dictadura stronista, resulta comprensible la necesidad del Brigadier de resguardar su propio cumplimiento de las órdenes recibidas. En este sentido, la grabación del interrogatorio no se orienta solo al registro de la información consignada, sino también a explicitar el trato dado y las pautas de convivencia impuestas. Sus destinatarios no eran solo los perseguidores de Perrotta sino también los superiores del interrogador. Se trata de imágenes y palabras que se encadenan en un sistema político policial y que encuentran allí la clave de su carácter performativo. Su propia emergencia resulta condicionada por la función represiva que deben cumplir tanto el audio del interrogatorio como las fotografías incluidas.

Por este motivo, y debido a que somos espectadores no previstos, podemos inquirir cómo se determina el fuera de campo de la violencia, el contracampo del que proceden las imágenes y los audios. ¿Cómo se inscribe en la materia sonora y visual la maquinaria destructiva de la que surgen?

Si entre el tiempo y el espacio de la violencia y el presente desde el que se monta el cortometraje se inscribe un hiato témporo-espacial, entonces es imprescindible interrogar cómo se construye la legibilidad de estas temporalidades estalladas y de estos espacios vacíos. ¿Cómo se registra en el audio y en la imagen la relación de poder? ¿Cómo se inscribe la violencia? Encina se involucra con estas preocupaciones y las aborda nuevamente a partir 
del montaje. Por una parte, en el plano de las imágenes fotográficas, recurre a una fragmentación de los cuerpos y objetos que privilegia la aparición de los números que constan en los registros y fichas policiales. Cada imagen aparece organizada numéricamente. En algunos casos son números presentes en lo pro-fotográfico; en otros se trata de números impresos sobre las fotografías. En ambas modalidades, la numeración se concibe como una materialización del poder clasificatorio, de la eficacia de una maquinaria de distribución y ordenamiento de los cuerpos. Por otra parte, frente a esta operatoria de un régimen escópico del control, Encina apela a la obstaculización de la mirada. En tanto la operatoria del poder consiste en la valoración de la transparencia y en la imposición de un régimen de la visibilidad absoluta, una estrategia posible de confrontación consiste en la sumatoria de mediaciones que dificulten el acceso irrestricto a los cuerpos de los resistentes.

En el cortometraje, Encina se detiene sobre una fotografía borrosa de un grupo humano que parece conformar una familia: dos cuerpos adultos y dos cuerpos infantiles que caminan por la pista de un aeropuerto saludando a un fuera de campo no especificado. A continuación irrumpe el detalle de una foto que muestra un grabador transportado por dos piernas masculinas. El resto del cuerpo queda, también, fuera de campo. Finalmente, en un tercer momento, se muestra la foto entera que evidencia que ambas imágenes pertenecen a una misma fotografía: la familia que llega y el oficial que los conduce y porta el grabador. El desglose y montaje de los tres tiempos construyen no solo un atisbo de narratividad, sino que confirman la potencia del montaje para articular y desarticular un documento histórico.

Distintas imágenes incluidas en ambos cortometrajes no pertenecen al Archivo del Terror, sino al archivo fotográfico y videográfico de la familia Encina. De esta manera, la realizadora suma un nuevo pliegue a su construcción archivística. La sumatoria de documentos de su propia biografía impone la voluntad de inventariar el mundo a partir de sí misma. Los planos capturados con una cámara Súper 8 entre 1975 y 1980 conforman un archivo personal. Así se inscribe su experiencia como niña durante la dictadura. Sin embargo, no hay nada en los cortometrajes que explicite el origen de este archivo familiar. La elección de no atribuir este material propicia una entrada oblicua en la historia y configura a quienes aparecen capturados por ese registro casero como sujetos políticos atravesados por la historia.

La inclusión de estas imágenes opera procesos de descontextualización y remontaje. Por un lado, este procedimiento remueve los archivos de los circuitos de visión previstos. Extrae los documentos del marco familiar y los introduce en un entorno que los desnaturaliza y los conforma, en esa travesía, 
como documentos de una historia no solo doméstica. En Le film de famille, Roger Odin concibe al film familiar como aquel realizado por un miembro de una familia a propósito de personajes, acontecimientos u objetos ligados de alguna manera con la historia de esa familia y para el uso privilegiado de sus miembros. En este sentido, su definición no depende solo de su capacidad para documentar e historizar lo cotidiano, sino de este alcance limitado. Por este motivo, la ruptura de este cerco implica la puesta en tensión del límite establecido entre lo público y lo privado.

Por otro lado, como señala Steve Anderson en Technologies of History, las home-movies promueven estrategias de remontaje dado que encarnan la historia en el micronivel de lo familiar. Así, la historia aparece figurada en individuos y familias y experimentada en esa dimensión cotidiana. La intervención sobre estos archivos compone un gesto performático y constituye un acto de memoria. En esta dirección, Antonio Weinrichter afirma que la apelación a las home movies supone una "operación de restitución de imagen a los marginados por la Historia oficial, de la que aquí se ofrece el contraplano" (2005: 82).

Esta restitución se manifiesta con particular intensidad en los films documentales sobre las dictaduras latinoamericanas de los años setenta: En memoria de los pájaros (Gabriela Golder, 2000) y M (Nicolás Prividera, 2007) en Argentina, En algún lugar del cielo (Alejandra Carmona, 2003), Mi vida con Carlos (Germán Berger, 2008) y El eco de las canciones (Antonia Rossi, 2010) en Chile y Por esos ojos (Virginia Martínez y Gonzalo Arijón, 1997) en Uruguay. Beatriz Tadeo Fuica (2015) explora este film para indagar las múltiples maneras en las que es posible contraponer las imágenes de la cotidianeidad familiar y el horror político que rodeaba su contexto de aparición. Los cortometrajes dirigidos por Encina pueden incluirse en esta tradición fílmica a través de esta tensión que se establece entre los archivos oficiales de la dictadura y las imágenes que registraron la experiencia de su propia familia.

En el epílogo de Arribo, una imagen abstracta en blanco y negro de una figura móvil inscribe el tiempo. En este vacío que sigue a la tensión audiosonido se habilita el espacio de la reflexión. El sonido sucio de Arribo y la ficha ajada de Familiar refuerzan el hiato temporal que separa a los espectadores actuales del origen de ese material de archivo. La sumatoria de esta heterogeneidad temporal favorece el proceso de desmontaje y remontaje emprendido por Encina. El montaje se pone en juego para desligar estas imágenes y audios de su función inicial y propiciar su conversión en una redención de los resistentes ante la dictadura. Si bien en un caso se congela el tiempo sobre su rostro y en otro se apela a su voz, en ambos se trata de proponer retratos hetero- 
doxos, fragmentarios, tensionados, arrancados de los prontuarios organizados por el poder institucional.

A su vez, en los dos se trata de pensar el trabajo sobre el archivo como un ritual que liga, como señala Georges Didi-Huberman (2015), la imago y la dignitas. El tributo rendido a la lucha llevada a cabo por los opositores a la dictadura stronista a través de la experiencia de Apolonia Flores y Benigno Perrotta recupera una certeza de Didi-Huberman: reescribir el archivo, operar sobre sus restos para repensar el presente supone, en un mismo gesto, cerrar los ojos de los muertos y mantener los ojos abiertos sobre los muertos.

\section{Referencias bibliográficas}

Anderson, S. (2011). Technologies of history. Visual media and the eccentricity of the past. Hanover: Dartmouth College Press.

Appadurai, A. (s.d.). Archive and aspiration. Disponible en https://archivepubl ic.wordpress.com/texts/arjun-appadurai/

Comolli, J. L. (2017). Cuerpo y cuadro, vol. II. Buenos Aires: Prometeo.

Comolli, J. L. (2016). Cuerpo y cuadro, vol. I. Buenos Aires: Prometeo.

Depes Portas, D. (2011). Lo que resta del tiempo: el archivo de Rosángela Rennó. Disponible en: www.derhuman.jus.gov.ar/conti/2011/10/mesa_1 2 /depes_portas_mesa_12.pdf

Derrida, J. (1997). Mal de archivo. Una impresión freudiana. Madrid: Trotta.

Didi-Huberman, G. (2015). Remontajes del tiempo padecido. El ojo de la historia 2. Buenos Aires: Biblos.

Farge, A. (1991). La atracción del archivo. Valencia: Alfonso el Magnanim.

Foster, H. (2002). Archives of Modern Art. October, 99: 81-95. Nueva York.

Giunta, A. (2010). Objetos mutantes. Sobre arte contemporáneo. Santiago: Palinodia.

Hirsch, M. (2012). The generation of postmemory. writing and visual culture after the Holocaust. Nueva York: Columbia University Press.

Odin, R. (1995). Le film de famille. Usage privé, usage public. París: Méridiens Klincksieck.

Sánchez Biosca, V. (2016). Miradas criminales, ojos de víctimas. Imágenes de la aflicción en Camboya. Buenos Aires: Prometeo.

Sekula, A. (2003). El cuerpo y el archivo. In G. Picazo \& J. Ribalta (ed.), Indiferencia y singularidad: la fotografía en el pensamiento artístico contemporáneo (pp. 137-187), Barcelona: Gustavo Gili. 
Tadeo Fuica, B. (2015). Presencias y ausencias: Uruguay y los documentales sobre hijos (des)aparecidos. Revista Cine Documental, 12: 169-196.

Wees, W. (1993). Recycled images. The art and politics of found footage films. Nueva York: Anthology Film Archives.

Weinrichter, A. (2005). Desvíos de lo real. El cine de no ficción. Madrid: $\mathrm{T} \& \mathrm{~B}$.

\section{Filmografía}

Arribo (2014), de Paz Encina.

Familiar (2014), de Paz Encina.

Hamaca paraguaya (2006), de Paz Encina.

Ventana sur (2011), de Paz Encina. 